\title{
Cointegration and Causality: An Application to Major Mango Markets in Pakistan
}

\author{
Abdul Ghafoor", Khalid Mustafa*, Khalid Mushtaq ${ }^{* * * * *}$ and \\ Abedullah ${ }^{* * * *}$
}

\begin{abstract}
Mangoes are one of Pakistan's most important fruits; the country is the world's fourth largest producer and exporter of mangoes. Integrated markets are those where price signals are transferred from one to another, allowing physical arbitrage to adjust any disturbances in these markets; integrated markets are thus a sign of efficiency. From this viewpoint, we investigate domestic integration among ten major mango markets, i.e., Lahore, Faisalabad, Multan, Gujranwala, Sargodha, Karachi, Hyderabad, Sukkur, Peshawar, and Quetta employing Johansen's cointegration approach and error correction model. Data on monthly wholesale prices data (PRs/100 kg) were obtained from the agricultural and livestock marketing advisor, Government of Pakistan. The results of the study confirm the presence of integration among major mango markets in Pakistan. These markets were able to adjust for 16 to $68 \%$ of disequilibrium in one month, implying that it takes almost two to six months to remove any disequilibrium and to move back to long-run equilibrium. The Granger causality test shows that the Karachi market has bidirectional causality with Lahore, Faisalabad, Multan, Hyderabad, and Sukkur, and a unidirectional relationship with the rest. An impulse response analysis was also conducted to check the stability of these markets given a standard error shock to the Karachi base market.
\end{abstract}

JEL Classification: A10, C01.

Keywords: Mangoes, cointegration, causality, Pakistan.

\footnotetext{
* , ${ }^{* *}$ Department of Marketing and Agribusiness, University of Agriculture, Faisalabad, Pakistan.

*** Department of Agricultural Economics, University of Agriculture, Faisalabad, Pakistan.

**** Department of Environment and Resource Economics, University of Agriculture, Faisalabad, Pakistan.
} 


\section{Introduction}

Fruits are an important sector of Pakistan's agricultural economy. They are valued as a rich source of minerals and vitamins providing more energy per unit weight than cereals. An increasing trend in population and changing consumer behavior toward a more balanced diet has increased the demand for fruit. Pakistan has a wide range of agro-climatic conditions, which allow the production of a variety of tropical and subtropical fruits. Among the major fruits of Pakistan, mangoes occupy the second position, coming after citrus fruits in terms of area and production: 192,000 ha of land $(2,458,000$ tonnes) are under citrus fruit cultivation and 156,000 ha $(1,753,000$ tonnes) under mangoes (Government of Pakistan 2005/06). While there is much emphasis on the area and production of mangoes in Pakistan, relatively little is known about how price transmission takes place in domestic mango markets. Such information is important for mango producers and other mango value chain role players since it affects their marketing decisions (buying and selling), which in turn affect decisions related to logistical matters and eventually the export potential of mangoes from Pakistan.

In a market-driven economy, the pricing mechanism is expected to transmit information to determine the flow of marketing activities. Pricing signals guide and regulate production, consumption, and marketing decisions over time, form, and place (Kohls and Uh1 1998). Identifying the causes of price differences in interregional or spatial markets has therefore become an important economic analytical tool to better understand markets.

In developing economies, there are several impediments to the efficient functioning of markets, particularly agricultural commodity markets. These include inappropriate transportation infrastructure, difficulties in access to market information, government-imposed restrictions on the movement of goods between regions, government monopoly over the marketing and distribution system, and poor enforcement of anti-trust regulations that result in price fixing and oligopolistic market structures. If markets are not well integrated then price signals can become distorted, leading to the inefficient allocation of resources. The marketable surplus generated by farmers could then result in depressed farm prices and diminishing income (Tahir and Riaz 1997).

Spatial market integration refers to co-movements or the long-run relationship among prices. It is defined as the smooth transmission of price signals and information across spatially separated markets (Golleti, et al 1995). Two trading markets are assumed integrated if price changes in one 
market are manifested in an identical price response in the other market (Barrett 1996). Market integration can also be defined as a measure of the extent to which demand and supply in one location are transmitted to the other (Negassa et a1 2003).

Market integration can be measured in terms of the strength and speed of price transmission between markets across various regions of a country. If markets are not well integrated, this often indicates the presence of either government policies or infrastructural and institutional bottlenecks that interfere with the efficient flow of goods and prices between markets. With market reforms, market integration is expected to increase, reflecting a more rapid and effective transmission of price signals between markets (Goletti and Babu 1994). Thus, market integration can be a good way of enhancing market efficiency through price stabilization, which may trickle down further to other markets.

We have focused on estimating empirically the degree of integration among major domestic mango markets in Pakistan. The paper is organized as follows: Section 2 reviews the existing literature on agricultural prices, Section 3 discusses the empirical approach we have used, Section 4 presents data and results, and Section 5 concludes the paper.

\section{Review of Literature}

Agricultural prices are used as a major policy tool in developing countries to change levels of production. Developing countries are often characterized by intensive government interventions to regulate their economies, seldom allowing free market forces to operate. Agricultural price trends can be a good indicator of market efficiency. Previously, price correlation coefficients were used to investigate whether or not markets were linked by price changes (Lale 1971, Blyn 1973, Timmer 1987, Dadi et al 1992). However, price correlation coefficients can be misleading due to the presence of trends (nonstationary data) in the data (Wyeth 1992). Regression analysis has also been used to analyze integration (Alexander and Wyeth 1994). This practice was modified using price variables in their first difference form, but this caused the loss of long-run information. Cointegration, on the other hand, allows a way of dealing with time series data that avoids spurious results, thus enhancing the authenticity of research findings. Johansen's approach to cointegration is now used widely to test the level of integration among markets.

Although fruits are an important component of Pakistan's agricultural economy, there has been little effort to investigate the pricing 
behavior of these crops. The existing literature includes studies on market structure, conduct, and margin analysis to evaluate the marketing efficiency of fruit crops in Pakistan (Scarborough and Takur 1973, Hays and McCoy 1977, Adekanaya 1982, and Kydd 1992).

Studies that focus on the pricing behavior of mangoes include Siddique (1977, 1979), Memon (1978), Khan (1980), Mohy-ud-din (1989), Khushk (1997), Khushk and Smith (1996), Lashari (1995), Khushk (2003), and Sharif (2004). Conducted in different parts of the country, most of these studies have used primary data to investigate pricing trends. The first three observe prevailing pricing practices to find the difference between farmers' and retail-level prices and thus estimate the level of marketing efficiency. Mohy-ud-din (1989) focuses on the export potential of mango and citrus fruits and examines price determination and its effect on the export potential of these fruit crops in Pakistan. Khushk (2003) conducts his study primarily on the mango crop to test the level of market integration using monthly average prices to calculate price correlation coefficients. Although the study shows that mango markets in Pakistan are integrated, it is limited in terms of the presence of trends in the dataset, which the authors do not tackle.

Sharif (2004) uses the weekly wholesale price of citrus fruits from four wholesale markets in Punjab for the period 1983 to 2003 to investigate the price relationships between these markets. The major findings of this analysis show that the Sargodha market is relatively better integrated with Faisalabad and Lahore than Multan since the price coefficient for the source market is greater than unity. However, the statistical test for integration reveals that the Lahore and Faisalabad markets were poorly integrated with Sargodha.

In addition to the literature on price behavior of the mango market, some literature examines the market integration of other major crops in Pakistan, i.e., Mushtaq et al (2006), (2007a), (2007b) (wheat, cotton, and rice); Mukhtar and Tariq (2008) (maize); and Lohano and Mari, (2006) (onions and potatoes). These studies use monthly average wholesale prices and test the level of market integration employing Johansen's approach. They find that markets are integrated in the long run, which provides a rationale for allowing market forces to operate freely in the country, leaving little reason for government interventions. 


\section{Empirical Methodology}

The concept of cointegration (Granger 1981) and methods of estimating a cointegrated relation or system (Engle and Granger 1987; Johansen 1988, 1991, 1995) provide a framework for estimating and testing for long-run equilibrium relationships between nonstationary integrated variables. Time series data are often nonstationary which, if regressed, provide spurious results that can be misleading. The first step in dealing with time series data is to test for the presence of a unit root in the individual time series of each model. The augmented Dickey-Fuller (ADF) test (Dickey and Fuller 1981), both with and without a deterministic trend, was used for this purpose. The number of lags in the ADF equation are chosen to ensure that serial correlation is absent, using the Breusch-Godfrey statistic (Greene 2000, p. 541). The ADF equation is required to estimate the following using the ordinary least squares (OLS) method.

$$
\Delta \mathrm{P}_{\mathrm{t}}=\alpha_{3}+\beta_{3} \mathrm{t}+\left(\phi_{3}-1\right) \mathrm{P}_{\mathrm{t}-1}+\sum \theta_{\mathrm{t}} \Delta \mathrm{P}_{\mathrm{t}-1}+\mu_{\mathrm{t}}
$$

Where $P_{t}$ is the series under investigation and $\mu_{t}$ is the error term. If two series are integrated of the same order, Johansen's (1988) procedure can be used to test for the long-run relationship between them. The approach adopted in this paper is based on Sims' (1980) methodology of a general unrestricted vector autoregressive (VAR) model where, unlike single equation methods, the exogenity of one price is not imposed ex ante; long-run market integration is examined using Johansen's cointegration procedure.

$$
\mathrm{X}_{\mathrm{t}}=\delta+\mathrm{A}_{1} \mathrm{X}_{\mathrm{t}-1}+\mathrm{A}_{2} \mathrm{X}_{\mathrm{t}-2}+\ldots \ldots+\mathrm{A}_{\mathrm{p}-1} \mathrm{X}_{\mathrm{t}-\mathrm{p}+1}+\varepsilon_{\mathrm{t}}
$$

Where $X_{t}$ is an ( $\left.n \times 1\right)$ vector of endogenous variables, $\delta$ is an $(n \times 1)$ vector of parameters, $A_{i}$ represents $(n \times n)$ matrices of parameters, and $\varepsilon_{t}$ is an ( $\mathrm{n} \times 1)$ vector of random variables. In this model, the price series for the ten major mango markets were endogenous variables and as such no exogenous variable was used. To test the hypothesis of integration and cointegration in equation (2), we transform it into its vector error correction form.

$$
\Delta \mathrm{X}_{\mathrm{t}}=\mu+\Gamma_{1} \Delta \mathrm{X}_{\mathrm{t}-1}+\Gamma_{2} \Delta \mathrm{X}_{\mathrm{t}-2}+\ldots \ldots+\Gamma_{\mathrm{k}-1} \Delta \mathrm{X}_{\mathrm{t}-\mathrm{k}+1}+\pi \mathrm{X}_{\mathrm{t}-\mathrm{k}}+\varepsilon_{\mathrm{t}}
$$

Where $x_{t}=\left[P_{1 t}, P_{2 t}\right]^{\prime}$, vector of endogenous variables, which are $I(1)$, $\Delta \mathrm{x}_{\mathrm{t}}=\mathrm{x}_{\mathrm{t}}-\mathrm{x}_{\mathrm{t}-1}, \mu$ is a $(2 \times 1)$ vector of parameters, $\Gamma_{1}, \ldots, \Gamma_{\mathrm{k}+1}$ and $\pi$ are $(2 \times 2)$ 
matrices of parameters, and $\varepsilon_{\mathrm{t}}$ is a $(2 \times 1)$ vector of white noise errors. Where $\pi$ is of a reduced rank, that is $r \leq 1$, it can be decomposed into $\pi=\alpha \beta^{\prime}$ and when $\mathrm{r}=1, \alpha=\left[\alpha_{1}, \alpha_{2}\right]^{\prime}$ is the adjustment vector and $\beta=\left[\beta_{1}, \beta_{2}\right]^{\prime}$ is the cointegrating vector. In this case, the above mentioned equation can be rewritten as equation (4):

$$
\left[\begin{array}{l}
\Delta \mathrm{P}_{1 \mathrm{t}} \\
\Delta \mathrm{P}_{2 \mathrm{t}}
\end{array}\right]=\left[\begin{array}{l}
\mu_{1} \\
\mu_{2}
\end{array}\right]+\sum_{\mathrm{i}-1}^{\mathrm{k}-1}\left[\begin{array}{ll}
\Gamma_{\mathrm{i}, 11} & \Gamma_{\mathrm{i}, 12} \\
\Gamma_{\mathrm{i}, 21} & \Gamma_{\mathrm{i}, 22}
\end{array}\right]\left[\begin{array}{l}
\Delta \mathrm{P}_{1 \mathrm{t}-\mathrm{i}} \\
\Delta \mathrm{P}_{2 \mathrm{t}-\mathrm{i}}
\end{array}\right]+\left[\begin{array}{l}
\alpha_{1} \\
\alpha_{2}
\end{array}\right]\left[\begin{array}{ll}
\beta_{1} & \beta_{2}
\end{array}\right]\left[\begin{array}{l}
\mathrm{P}_{1 \mathrm{t}-\mathrm{k}} \\
\mathrm{P}_{2 \mathrm{t}-\mathrm{k}}
\end{array}\right]+\left[\begin{array}{l}
\varepsilon_{1 \mathrm{t}} \\
\varepsilon_{2 \mathrm{t}}
\end{array}\right]
$$

Harris (1995, p. 96) holds that there are three realistic models (denoted as models 2-4) implicit in the above equation. Mode1 2 shows no linear trends in the levels of the endogenous I (1) variables and the firstdifferenced series have zero means; here, the intercept is restricted to the cointegration space. Model 3 shows linear trends in the levels of the endogenous I (1) variables and there is an intercept only in the short-run model. Model 4 does not account for any long-run linear growth and shows a linear trend in the cointegration vectors. The Pantula principle (Harris 1995 , p. 97) is used to test the joint hypothesis of both rank and deterministic components (Johansen 1992).

Even when cointegration has been established within the series, there may still be disequilibrium in the short run, i.e., price adjustments across markets may not happen instantaneously; markets can take time to adjust. Another important implication of cointegration and the error correction representation is that cointegration between two variables implies the existence of causality (in the Granger sense) in at least one direction (Granger 1988). Nevertheless, if two markets are integrated, the price in one market, $\mathrm{P}_{1}$, would commonly be found to Granger-cause the price in the other market, $\mathrm{P}_{2}$ and/or vice versa. Therefore, Granger causality provides additional evidence as to whether and in which direction price transmission is occurring between two series. If the series $P_{i t}$ and $P_{i j}$ are $I$ (1) and cointegrated, then the ECM model is represented by the following equations.

$$
\begin{aligned}
& \Delta P_{i t}=\alpha_{0}+\sum_{t=1}^{n} \beta_{i} \Delta P_{(t-1) i}+\sum_{t=1}^{n} \beta_{j} \Delta P_{(t-1) j}+\delta E C T_{t-1}+\mu_{t} \\
& \Delta P_{j t}=\varphi_{0}+\sum_{t=1}^{n} \sigma_{j} \Delta P_{(t-1) j}+\sum_{t=1}^{n} \sigma_{i} \Delta P_{(t-1) i}+\lambda E C T_{t-1}+\varepsilon_{t}
\end{aligned}
$$


Where $\Delta$ is the difference operator, $\mathrm{P}_{j t}$ is the price series in the Karachi market ( $i=1), P_{i j}$ is the price series in other markets $(j=2 \ldots \ldots 10)$ $\mu_{t}$ and $\varepsilon_{t}$ are white noise error terms, $E C T_{t-1}$ is the error correction term (adjustment vector) derived from the long-run cointegrating relationship, while $\mathrm{n}$ is the optimal lag length orders of the variables which are determined by using the general-to-specific modeling procedure (Hendry and Ericsson 1991). The null hypotheses are: $\mathrm{P}_{i t}$ will Granger-cause $\mathrm{P}_{j t}$ if $\mu_{t}$ $\neq 0$. Similarly, $\mathbf{P}_{j t}$ will Granger-cause $\mathbf{P}_{i t}$ if $\varepsilon_{t} \neq 0$. To implement the Granger causality test, F-statistics are calculated under the null hypothesis that all the coefficients of $\mu_{t}$ and $\varepsilon_{t}=0$.

An impulse-response approach can also be used to derive additional information about the dynamic interrelationships among prices. Impulseresponse analysis is employed to investigate the mechanism of shocks. This concept has been used to analyze the impact of price shocks and the way in which shocks are transmitted among market prices. It is based on the foundation that the economy's dynamic behavior can be well explained by random impulses generated over time by a constant linear structure. Potter (1998) improved the standard linear technique of an impulse-response function analysis to the non-linear case by defining a generalized impulseresponse function as a random variable in the underlying space of the time series. In our study, an impulse-response function is estimated as an attempt to come to a better understanding of the dynamic price interrelationships, how price shocks are transmitted, and how long it takes for shocks to be eliminated in alternate markets.

\section{Data and Results}

We have used monthly wholesale price $(\mathrm{Rs} / 100 \mathrm{~kg})$ data for mangoes for the period June 1990 to July 2006 in logarithmic form. Data were obtained from the agricultural and livestock marketing advisor, Government of Pakistan. The study analyzes price transmission in ten selected mango markets in Pakistan: Quetta, Peshawar, Lahore, Faisalabad, Multan, Sargodha, Gujranwala, Karachi, Sukkur, and Hyderabad. The criteria for selecting these markets include net market positions (surplus or deficit area), geographical distribution, data availability, and the volume of trade or importance of the market to the national mango trade flow and their link to and importance in the export of mangoes. Karachi, as the largest market, was set as base market for the analysis. 
Summary statistics are presented in Table-1, which shows that the minimum values of the average price varied from Rs800/100 $\mathrm{kg}$ in the Faisalabad market to Rs.1,150/100 kg in the Quetta market; maximum values for the average price varied from Rs.2,790/100 kg in the Hyderabad market to Rs.3,450/100 kg in the Quetta market. Average prices were found to be Rs.2,023/100 kg in Karachi, Rs.2,028/100 kg in Peshawar, Rs.1,764/100 kg in Multan, and Rs.1,851/100 kg in Faisalabad. The maximum standard deviation in price was in Karachi, which remained 574; the minimum standard deviation was 430 in Hyderabad.

Table-1: Description of Data (Rs. /100Kgs)

\begin{tabular}{lcccc}
\hline Market & Minimum & Maximum & Mean & Std. Deviation \\
\hline Lahore & $1,050.00$ & $3,350.00$ & $1,971.1569$ & 555.8871 \\
Faisalabad & 800.00 & $3,000.00$ & $1,851.5490$ & 522.1870 \\
Sargodha & 923.00 & $2,950.00$ & $1,912.3725$ & 572.7451 \\
Multan & $1,062.00$ & $2,800.00$ & $1,764.5882$ & 437.1369 \\
Gujranwala & 950.00 & $2,900.00$ & $1,949.6471$ & 503.9044 \\
Karachi & $1,070.00$ & $3,370.00$ & $2,023.7451$ & 574.1763 \\
Hyderabad & $1,052.00$ & $2,790.00$ & $1,747.3922$ & 430.8972 \\
Sukkur & 943.00 & $2,920.00$ & $1,917.3725$ & 553.5545 \\
Peshawar & $1,110.00$ & $3,410.00$ & $2,028.8039$ & 553.0736 \\
Quetta & $1,150.00$ & $3,450.00$ & $2,071.1569$ & 555.8871 \\
\hline
\end{tabular}

The appendix at the end of this paper includes graphs of the price series. An increasing trend was found in the data over the time, which remained consistent for the said time period. Prices were found to be high at the beginning of each season, then decreasing in the middle, and rising again at the end: this trend seemed common for all major mango markets (see graphs). The consistent behavior of prices left little justification for any structural break in the dataset, so integration was tested for the whole time period to check the level of price association between markets. The consumer price index (CPI) was also graphed for the given time period and showed an increasing trend: this behavior was consistent with mango prices.

Table- 2 reports the unit root results using ADF tests both with and without a linear trend. The null hypothesis is that the variable observed has a unit root against the alternative that it does not. Both models 
indicate that the null of the unit root cannot be rejected for all price series as the absolute values of the ADF statistics are well below the $95 \%$ critical value of the test statistics. Thus, we conclude that all the price series are nonstationary.

Table-2: Unit Root Test

\begin{tabular}{lcc}
\hline Variables & Non-Trended Model & Trended Model \\
\hline Lahore & -0.27 & -2.65 \\
Faisalabad & -1.69 & -2.94 \\
Sargodha & -0.88 & -1.35 \\
Multan & -0.25 & -2.71 \\
Gujranwala & -1.51 & -2.50 \\
Karachi & -0.37 & -3.05 \\
Hyderabad & -0.22 & -3.30 \\
Sukkur & -0.88 & -1.41 \\
Peshawar & -0.24 & -2.64 \\
Quetta & -0.22 & -2.65 \\
Critical Values at 95\% & -2.93 & -3.50 \\
Confidence Level & & \\
\hline
\end{tabular}

In order to test the level or number of unit roots in the data, a unit root test of first difference was conducted that showed the number of unit roots equal to 1 since the data becomes stationary after the first difference as absolute values of the ADF statistics are now greater than the $95 \%$ critical value of the test statistics. The results are depicted in Table-3. 
Table-3: Unit Root Test of First Difference Series

\begin{tabular}{lcc}
\hline Variables & Non-Trended Model & Trended Model \\
\hline Lahore & -5.90 & -5.85 \\
Faisalabad & -17.60 & -17.60 \\
Sargodha & -5.87 & -5.91 \\
Multan & -5.55 & -5.50 \\
Gujranwala & -6.02 & -6.05 \\
Karachi & -6.25 & -6.18 \\
Hyderabad & -18.06 & -1784 \\
Sukkar & -5.25 & -5.28 \\
Peshawar & -5.88 & -5.83 \\
Quetta & -5.89 & -5.84 \\
Critical Values at 95\% & -2.97 & -3.58 \\
Confidence Level & & \\
\hline
\end{tabular}

After testing for a unit root, the next step is to test for cointegration by applying Johansen's procedure to mango prices. The first step is to select the order of the vector autoregressive model. We use the SBC and AIC criteria (Sims 1980), to test the null hypothesis that the order of the VAR is $\mathrm{k}$ against the alternative that it is 4 where $\mathrm{k}=0,1, \ldots, 4$ and for all cases, $\mathrm{k}=1$. The values of the results showed the order of VAR equal to 1, as the largest values were found to be at order 1 .

The second step in the Johansen procedure is to test the presence and number of cointegration vectors among the series in each model. We tried different models but model 2 (cointegration with restricted intercepts and no trends in the VAR) was found to be the most appropriate. Table-3 presents Johansen's cointegration results. We conducted two tests, eigenvalues and trace tests, to check the number of cointegrating vectors, which were found to be 5 in both the above mentioned tests. These tests confirm that all ten major mango markets in Pakistan are well integrated and price signals are transferred from one to the other to ensure efficiency. 
Table-4: Cointegration Results (Overall)

\begin{tabular}{lcccc}
\hline \multicolumn{5}{c}{$\begin{array}{l}\text { List of the Variables included in the Unrestricted VAR: } \\
\text { LK, LL, LM, LF, LG, LH, LSK, LS, LP, LT }\end{array}$} \\
\hline Ho & $\mathbf{H}_{\mathbf{A}}$ & Model 2 & Model 3 & Model 4 \\
\hline \multicolumn{5}{c}{ Cointegrating } \\
\multicolumn{5}{c}{ LR Test Based on Maximal Eigenvalues of the Stochastic } \\
Matrix
\end{tabular}

95\% Critical Values in Parentheses.

Note: LK represents the price series in logarithm form for Karachi, whereas LL, LM, LF, LG, LH, LSk, LS, LP and LT represent the price series in Lahore, Multan, Faisalabad, Gujranwala, Hyderabad, Sukkur, Sargodha, Peshawar, and Quetta respectively.

Model 2: Cointegration with restricted intercepts and no trends in the VAR; Model 3: Cointegration with unrestricted intercepts and no trends in the VAR; Model 4: Cointegration with unrestricted intercepts and restricted trends in the VAR.

Even though regional markets are geographically dispersed and spatially segmented, spatial pricing relationships reveal that mango prices are linked, indicating that all mango exchange locations belong to the same economic market. After testing market integration for major mango markets on an overall basis, we tested further the integration between pairs of markets. In pair-wise analysis, the order of VAR was selected as 1 .

Maximal eigenvalues and trace tests were used to check the level of market integration between pairs of markets. Again, three models were tried but model 2 was found to be the most appropriate. Results show that both tests complement each other by identifying one cointegrating vector for each pair, stating that all market pairs are integrated with each other. This shows that Karachi, as a base market, transfers price signals to other mango markets. The results of the cointegration analysis are depicted in Table-5. 
Table-5: Cointegration Results (Pair Wise)

\begin{tabular}{|c|c|c|c|c|c|}
\hline \multicolumn{6}{|c|}{ List of the Variables included in the Unrestricted VAR: } \\
\hline & & & & & \\
\hline \multirow[b]{2}{*}{ Markets Pair } & Ho & $\mathbf{H}_{\mathrm{A}}$ & Model 2 & Model 3 & Model 4 \\
\hline & \multicolumn{5}{|c|}{$\begin{array}{c}\text { Cointegrating LR Test Based on Maximal Eigenvalues of the } \\
\text { Stochastic Matrix }\end{array}$} \\
\hline arachi- & $\mathrm{r}=0$ & $\mathrm{R}=1$ & $29.66(15.87)$ & $29.65(14.85)$ & $47.16(19.22)$ \\
\hline Lahore & $\mathrm{r}<=1$ & $\mathrm{R}=2$ & $6.45(9.16)$ & & 39) \\
\hline \multirow[t]{2}{*}{ Karachi- Multan } & $\mathrm{r}=0$ & $\mathrm{R}=1$ & $38.72(15.87)$ & $38.65(14.85)$ & 45.36 \\
\hline & $\mathrm{r}<=1$ & $\mathrm{R}=2$ & & & 8.54 \\
\hline Karachi- & $\mathrm{r}=0$ & $\mathrm{R}=1$ & 34.08 & $(14.85)$ & 43.5 \\
\hline bad & $\mathrm{r}<=1$ & $\mathrm{R}=2$ & & & 7.28 \\
\hline Kara & $\mathrm{r}=0$ & $\mathrm{R}=1$ & $26.85(15.87)$ & 14.85) & 42.8 \\
\hline Sujp & $\mathrm{r}<=1$ & $\mathrm{R}=2$ & & & 10.7 \\
\hline Kara & $\mathrm{r}=0$ & $\mathrm{R}=1$ & $(15.87)$ & 25.2 & 42.3 \\
\hline & $\mathrm{r}<=1$ & $\mathrm{R}=2$ & & & 12.02 \\
\hline & $r=0$ & $\mathrm{R}=1$ & 24.1 & $.85)$ & 42.9 \\
\hline $\mathrm{dkk}$ & $\mathrm{r}<=1$ & $\mathrm{R}=2$ & & & 10.1 \\
\hline & $r=0$ & $\mathrm{R}=1$ & & 45.3 & 49.2 \\
\hline & $\mathrm{r}<=1$ & $\mathrm{R}=2$ & 7. & & 11.5 \\
\hline & $r=0$ & $\mathrm{R}=1$ & & 31. & 48. \\
\hline & $\mathrm{r}<=1$ & $\mathrm{R}=2$ & & & \\
\hline & $\mathrm{r}=0$ & $\mathrm{R}=1$ & 30. & 30. & 46. \\
\hline Quetta & $\mathrm{r}<=1$ & $\mathrm{R}=2$ & $7.61(9.16)$ & $7.22(8.07)$ & \\
\hline \multicolumn{6}{|c|}{ Cointegrating LR Test Based on Trace of the Stochastic Matrix } \\
\hline Karachi- & $r=0$ & $\mathrm{R}=1$ & & $35.90(17.86)$ & 76.9 \\
\hline Lahore & $\mathrm{r}<=1$ & $\mathrm{R}=2$ & & & \\
\hline \multirow[t]{2}{*}{ Karachi- Multan } & $\mathrm{r}=0$ & $\mathrm{R}=1$ & 46. & 45.8 & 83.9 \\
\hline & & $\mathrm{R}=2$ & & & \\
\hline & $\mathrm{r}=0$ & $\mathrm{R}=1$ & 40.3 & 44.5 & 80.8 \\
\hline & $\mathrm{r}<=1$ & $\mathrm{R}=2$ & & & \\
\hline & $\mathrm{r}=0$ & $\mathrm{R}=1$ & 34.0 & 33.6 & 69.6 \\
\hline Gujranwala & $\mathrm{r}<=1$ & $\mathrm{R}=2$ & & & 10.70 \\
\hline Karachi- & $\mathrm{r}=0$ & $\mathrm{R}=1$ & $32.22(20.18)$ & $31.70(17.86)$ & $64.36(25.77)$ \\
\hline & $\mathrm{r}<=1$ & $\mathrm{R}=2$ & & $6.50(8.07)$ & $12.02(12.39)$ \\
\hline arachi- & $\mathrm{r}=0$ & $\mathrm{R}=1$ & $31.12(20.18)$ & $30.58(17.86)$ & $63.06(25.77)$ \\
\hline & $\mathrm{r}<=1$ & $\mathrm{R}=2$ & & & 10.13 \\
\hline & $\mathrm{r}=0$ & $\mathrm{R}=1$ & $53.19(20.18)$ & 52.74 & $91.81(25.77)$ \\
\hline & $\mathrm{r}<=1$ & $\mathrm{R}=2$ & $7.79(9.16)$ & $8.07)$ & 12.39) \\
\hline & $\mathrm{r}=0$ & $\mathrm{R}=1$ & $39.26(20.18)$ & 17.86) & 25.77) \\
\hline & $\mathrm{r}<=1$ & $\mathrm{R}=2$ & & 7.22( & 12.39) \\
\hline & & $\mathrm{R}=1$ & $38.07(20.18)$ & $37.64(17.86)$ & $76.23(25.77)$ \\
\hline Quetta & $\mathrm{r}<=1$ & $\mathrm{R}=2$ & $7.61(9.16)$ & $7.22(8.07)$ & $9.30(12.39)$ \\
\hline
\end{tabular}

95\% Critical Values in Parentheses. 
Even if we demonstrate market integration through cointegration, there could be disequilibrium in the short run, i.e., price adjustment across markets may not happen instantaneously. It may take some time for spatial price adjustments to occur. The error correction model takes into account the adjustment of short-run and long-run disequilibrium in markets and time to remove disequilibria in each period. Table- 6 shows that $16-68 \%$ of disequilibrium is removed in each period, i.e., one month in the mango markets of Pakistan. This implies that economic agents take between two to six months to adjust to a long-run equilibrium. For example, in Lahore, $66 \%$ of the disequilibrium is removed in each period, i.e., one month, while $68 \%$ of the disequilibrium is removed in Multan. Other mango markets follow the same pattern of adjustment to shocks except Gujranwala, Peshawar, and Quetta, which show nonsignificant results.

Table-6: Adjustment Vectors from Error Correction Model

\begin{tabular}{lccc}
\hline Price Relationship: Karachi & Coefficient & T-value & P- value \\
\hline Lahore & -0.667 & -2.71 & $0.033^{*}$ \\
Multan & -0.681 & -2.12 & $0.063^{*}$ \\
Faisalabad & -0.396 & -2.38 & $0.007^{*}$ \\
Gujranwala & -0.161 & -0.728 & 0.470 \\
Sargodha & -0.428 & -2.00 & $0.051^{*}$ \\
Sukkur & -0.43 & -2.03 & $0.047^{*}$ \\
Hyderabad & -0.531 & -2.40 & $0.002^{*}$ \\
Peshawar & -0.24 & -1.11 & 0.272 \\
Quetta & -0.20 & -0.912 & 0.366 \\
\hline
\end{tabular}

* Significant at 5\% Confidence Level.

Granger causality is also estimated between pairs of domestic mango markets in Pakistan. Granger causality means the direction of price formation between two markets and related spatial arbitrage, i.e., physical movement of the commodity to adjust for these prices differences. Table-7 gives the results of the Granger causality test which show that, in five cases, i.e., Lahore, Faisalabad, Multan, Hyderabad, and Sukkur, there exists bidirectional causality. In these cases, the Karachi Granger causes price formation in the concerned mango markets which in turn provide feedback to the Karachi base market as well. In the case of the other four markets, i.e., Sargodha, Gujranwala, Peshawar, and Quetta, there exist unidirectional relationships between the Karachi base market and concerned mango 
markets. This implies that the Karachi market Granger causes price formation in these four markets but they do not provide any feedback to the Karachi base market.

Table-7: Granger Causality from Error Correction Model

\begin{tabular}{lccc}
\hline Causality & F-Statistics & P-Value & Direction \\
\hline Karachi $\rightarrow$ Lahore & 3.31 & $0.028^{*}$ & \multirow{2}{*}{ Bidirectional } \\
Lahore $\rightarrow$ Karachi & 4.37 & $0.009^{*}$ & \\
Karachi $\rightarrow$ Multan & 4.77 & $0.006^{*}$ & Bidirectional \\
Multan $\rightarrow$ Karachi & 3.12 & $0.035^{*}$ & \\
Karachi $\rightarrow$ Faisalabad & 3.49 & $0.023^{*}$ & Bidirectional \\
Faisalabad $\rightarrow$ Karachi & 4.47 & $0.008^{*}$ & \\
Karachi $\rightarrow$ Gujranwala & 4.00 & $0.013^{*}$ & Unidirectional \\
Gujranwala $\rightarrow$ Karachi & 1.92 & 0.140 & \\
Karachi $\rightarrow$ Sargodha & 5.91 & $0.005^{*}$ & Unidirectional \\
Sargodha $\rightarrow$ Karachi & 1.70 & 0.171 & \\
Karachi $\rightarrow$ Sukkur & 3.96 & $0.014^{*}$ & Bidirectional \\
Sukkur $\rightarrow$ Karachi & 2.80 & $0.050^{*}$ & \\
Karachi $\rightarrow$ Hyderabad & 2.48 & $0.073^{*}$ & Bidirectional \\
Hyderabad $\rightarrow$ Karachi & 5.29 & $0.003^{*}$ & \\
Karachi $\rightarrow$ Peshawar & 3.12 & $0.035^{*}$ & Unidirectional \\
Peshawar $\rightarrow$ Karachi & 1.50 & 0.204 & \\
Karachi $\rightarrow$ Quetta & 3.29 & $0.029^{*}$ & Unidirectional \\
Quetta $\rightarrow$ Karachi & 1.34 & 0.240 & \\
\hline
\end{tabular}

* Significant at 5\% Confidence Level.

An impulse-response analysis was also carried out to better understand dynamic price interrelationships, how price shocks are transmitted, and how long it takes for shocks to be eliminated in alternate markets. Figure 1 depicts the impulse response in Lahore due to one standard error price shock in the Karachi market. It only takes 1 month for the Lahore market to eliminate the price shock and converge onto long-run equilibrium. These responses are consistent with long-run market integration. 
Figure 1: Impulse Response of Lahore to Standard Error Shock in Karachi

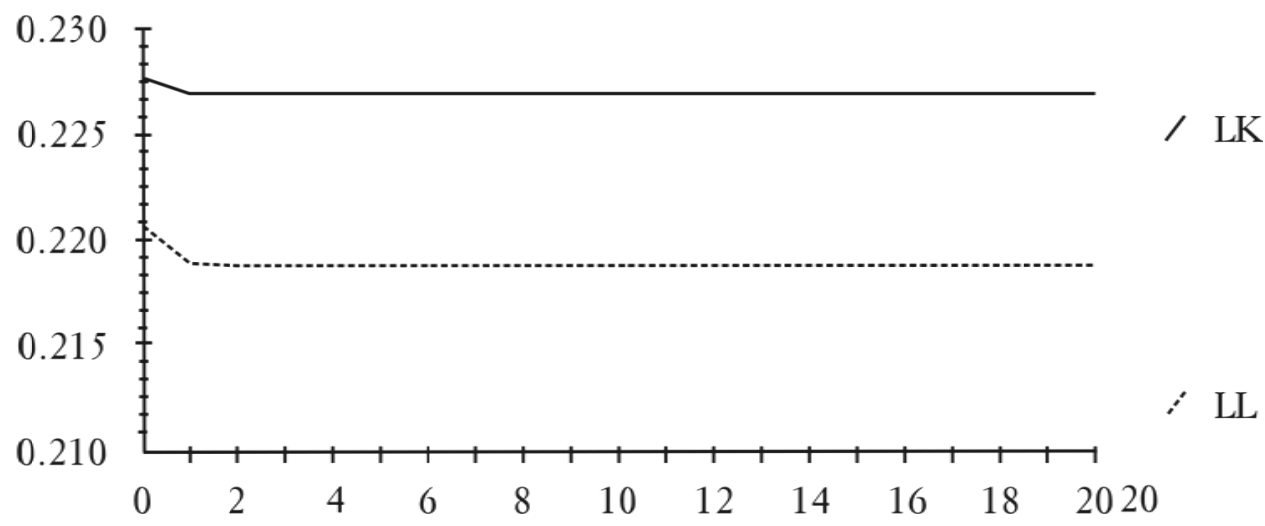

Figure 2 depicts a standard error shock in Karachi and its response in Faisalabad; the graph shows that Faisalabad adjusted to the shock within 1 month.

Figure 2: Impulse Response of Faisalabad to Standard Error Shock in Karachi

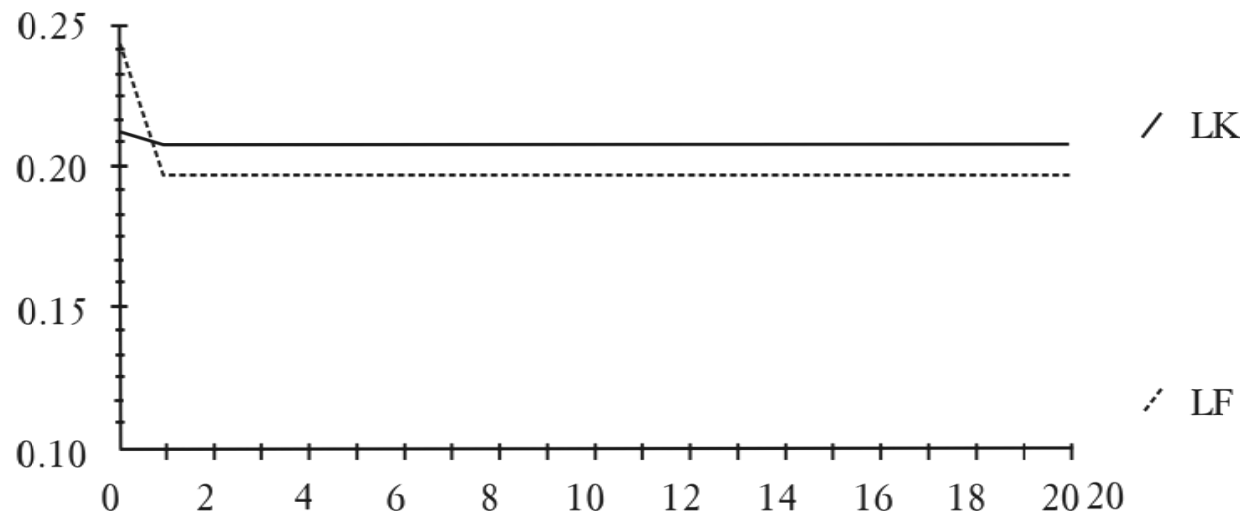


Figure 3 depicts a standard error shock in Karachi and its response in Sargodha, which shows that it took the latter almost 3 months to adjust to the shock. The longer adjustment period relative to Faisalabad and Lahore is justified by the adjustment vector, which in Sargodha's case was found to be nonsignificant.

Figure 3: Impulse Response of Sargodha to Standard Error Shock in Karachi

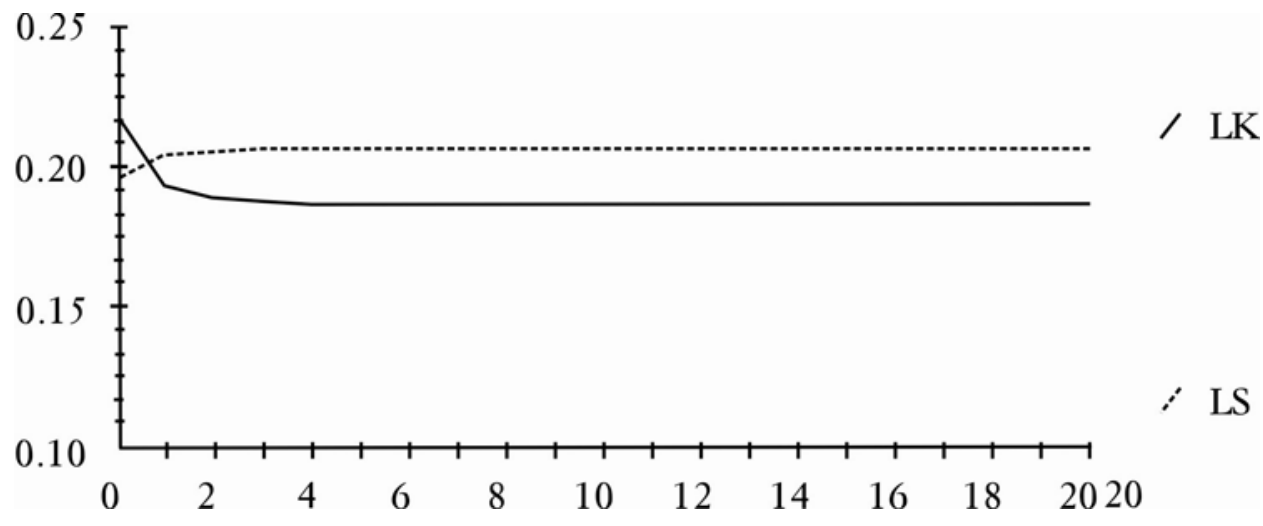

Figure 4 depicts the Multan market, which in response to a shock in Karachi adjusts within less than a month. This shows that there are strong price linkages between the two markets and also justifies the physical arbitrage adjusting for any disequilibrium between the two markets.

Figure 4: Impulse Response of Multan to Standard Error Shock in Karachi

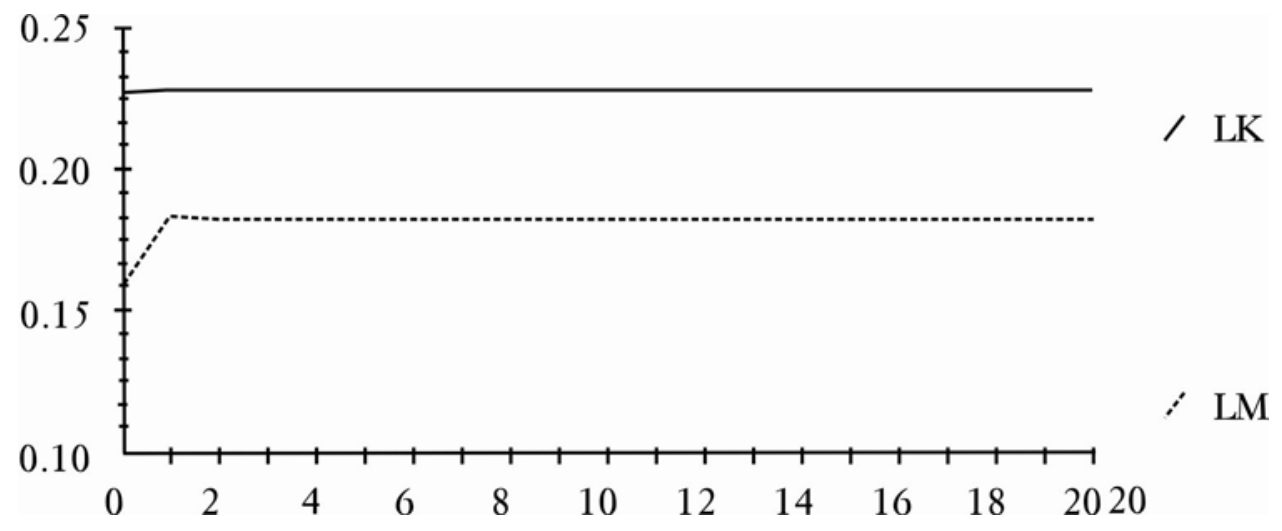


Gujranwala took almost 3 months to adjust from disequilibrium and to move toward a long-run equilibrium (Figure 5).

Figure-5: Impulse Response of Gujranwala to Standard Error shock in Karachi

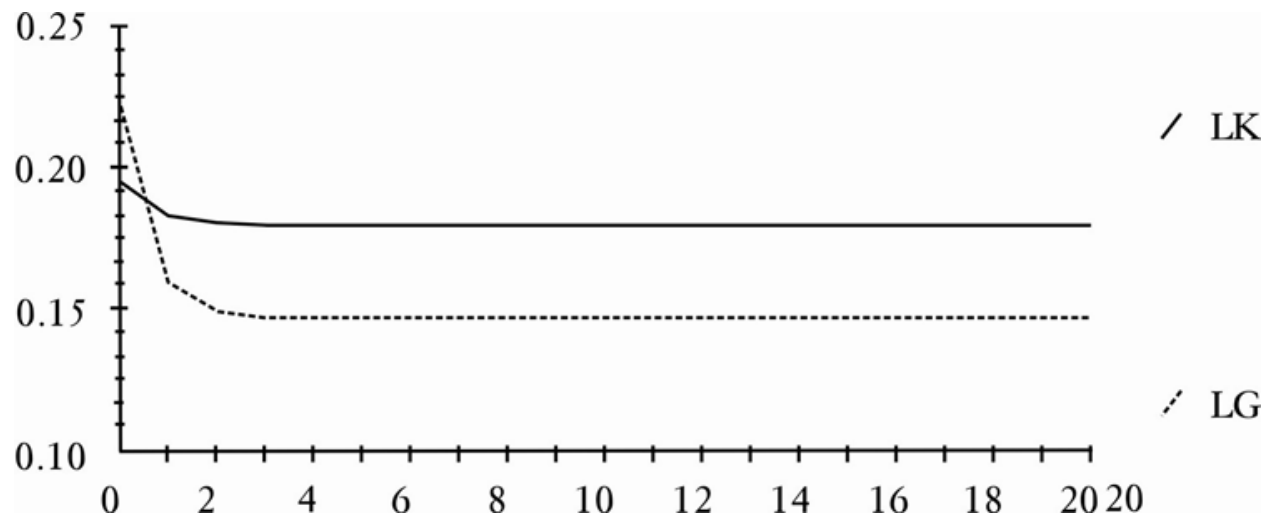

The other four markets, i.e., Sukkur, Hyderabad, Peshawar, and Quetta behaved in a similar fashion. In response to a standard error shock in the Karachi market, the above mentioned markets adjusted within a month (Figures 6-9).

Figure 6: Impulse Response of Hyderabad to Standard Error Shock in Karachi

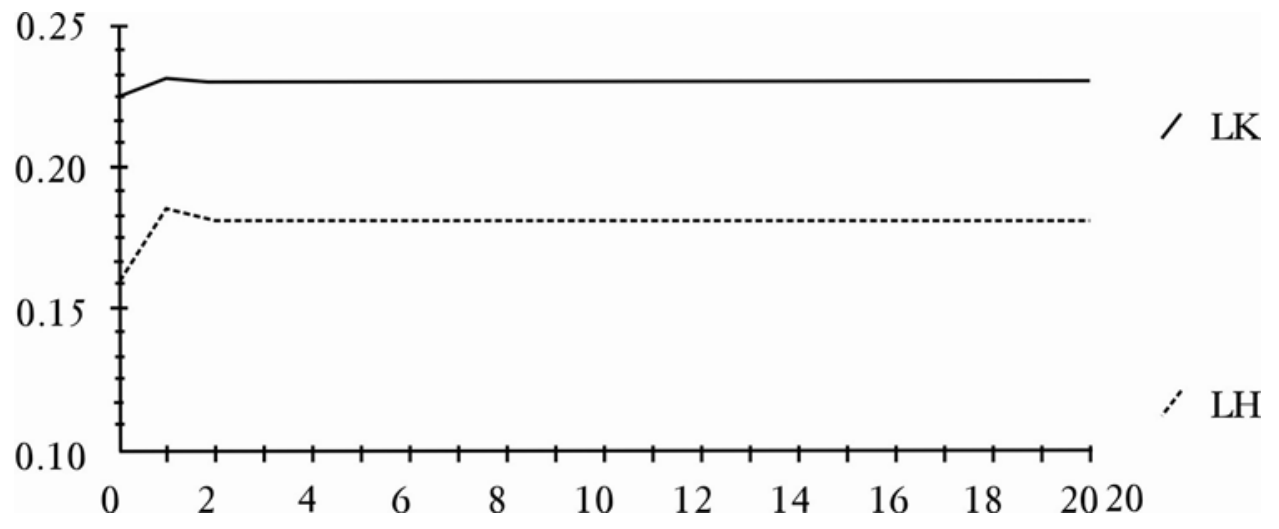


Figure 7: Impulse Response of Sukkur to Standard Error Shock in Karachi

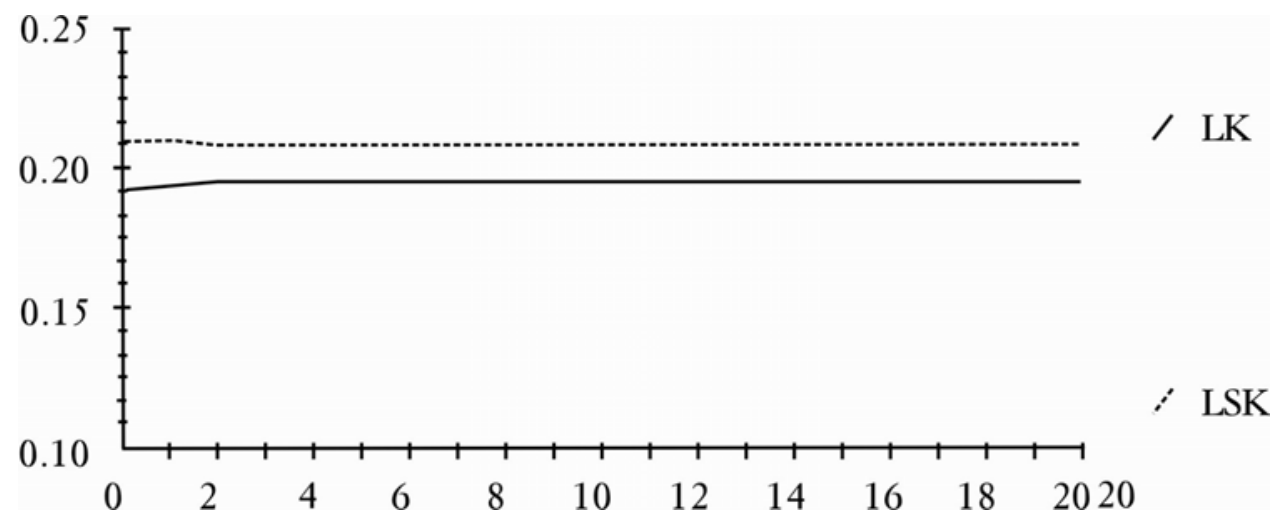

Figure-8: Impulse Response of Peshawar to Standard Error Shock in Karachi

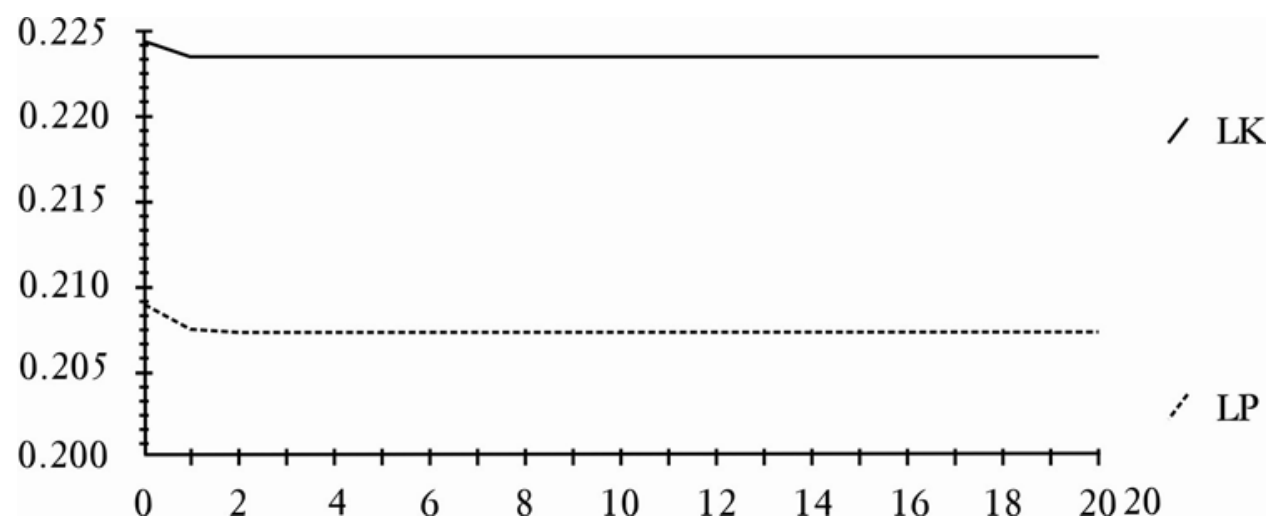

Figure-9: Impulse Response of Quetta market to Standard Error Shock in Karachi

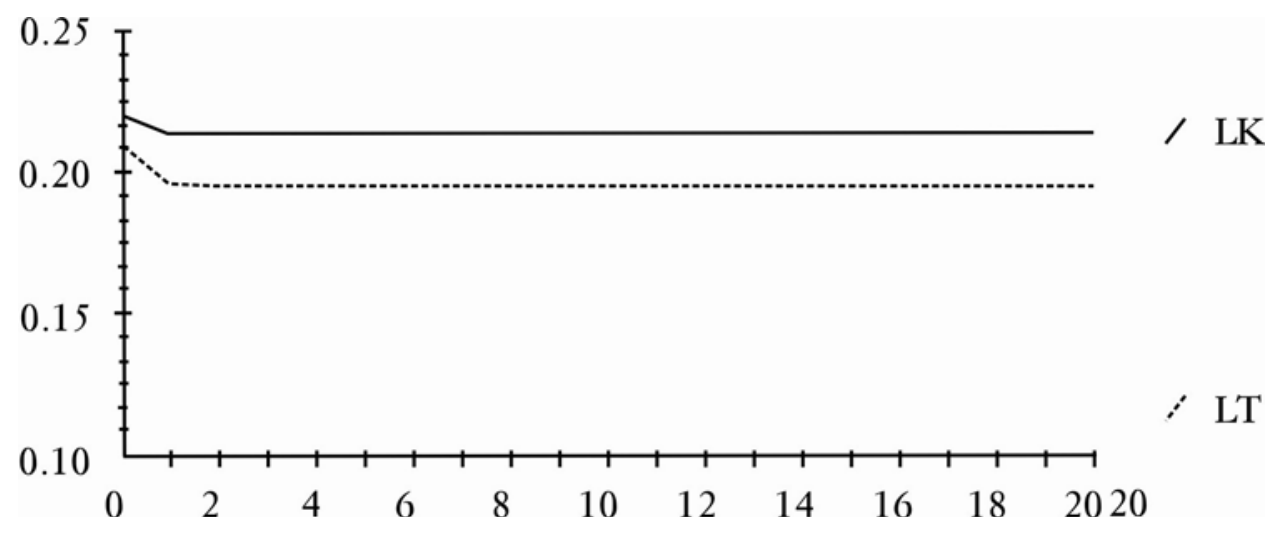




\section{Conclusion and Implications}

In this paper, we have tried to investigate the level of market integration among major mango markets in Pakistan by using monthly wholesale price data $(\mathrm{Rs} / 100 \mathrm{~kg}$ ) for the period from 1990 to 2006 . Market integration was tested at two levels, i.e., overall and between pairs of mango markets designating Karachi as a base market. In addition to market integration analysis, adjustment vectors were also calculated using an error correction model, which explained the adjustment mechanism in case of a deviation from long-run equilibrium. Granger causality in price formation and related spatial arbitrage was also calculated to verify the direction of pricing relationships between different markets. Finally, an impulse response analysis was also conducted to show the response of different markets to a standard error shock in the Karachi market and markets' subsequent adjustment patterns.

Cointegration analysis was conducted in three steps. First, the ADF test was conducted to check the presence of a unit root; second, the order of VAR was selected using SBC and AIC criteria; and third, cointegration was verified using Johansen's approach. According to our overall market integration analysis, all major mango markets were integrated with each other, which showed the co-movement of prices. This indicates market efficiency. Pair-wise market integration analysis also confirmed that all markets were integrated with the Karachi base market. The adjustment vector implied that about $16-68 \%$ of disequilibrium is removed from markets in each period, i.e. one month, which implies that economic agents take almost 2 to 6 months to return to long-run equilibrium.

The adjustment to long-run equilibrium is a good sign with regard to the adjustment response to price differences in major mango markets of Pakistan. Granger causality results showed that, in five cases, i.e., Lahore, Faisalabad, Hyderabad, Multan, and Sukkur, there was bidirectional causality with Karachi as the base market. This implies that the Karachi Granger causes price formation in those markets, which then feed back into the Karachi market. In the case of the other four markets, there was found to be unidirectional causality from Karachi to those markets, indicating that only the Karachi market Granger causes price formation in those markets without any feedback into the base market.

Impulse response analysis was also conducted, which captured the effect of a standard error shock to the Karachi market and its impact on the other markets concerned. Only two markets, i.e., Sargodha and Gujranwala, took 3 months to adjust to equilibrium in response to one standard error 
shock to Karachi; all other markets adjusted roughly within one month. Thus, mango markets in Pakistan are well integrated in terms of price responses, suggesting that the government should continue supporting the private sector to operate freely. 


\section{References}

Adekanye T. O., 1982, "Marketing Margins for Food: Some Methodological Issues and Empirical Findings for Nigeria," Canadian Journal of Agricultural Economics, Vo1. 30 (2) : 333-344.

Alexander, C. and J. Wyeth, 1994, Cointegration and Market Integration: An Application to the Indonesian Rice Market," The Journal of Development Studies, Vo1. 30 (2) : 303-328.

Barret, C. B., 1996, "Markets Analysis Methods: Are our Enriched Too1 Kits Well Suited to Enlivened Markets?" American Journal of Agricultural Economics, Vo1. 78 : 825-829.

Blyn, G., 1973, "Price Series Correlation as a Measure of Market Integration," Indian Journal of Agricultural Economics, Vo1. 28 (2) : 56-59.

Dadi, L., A. Negassa and S. Franze1, 1992, "Marketing of Maize and Tef in Western Ethiopia," Implications for Policy Following Liberalization: Food Policy, Vo1. 17 (3) : 201-213.

Dickey, D. and Fuller, W., 1979, "Distribution of the Estimators for Autoregressive Time Series with a Unit Root," Journal of the American Statistical Association, Vo1. 74 : 427-431.

Dickey, D.A. and Fuller, W.A., 1981, "Likelihood Ratio Statistics for Autoregressive Time Series with a Unit Root," Econometrica, Vo1. $49: 1057-1072$.

Engle, R.F. and Granger, C.W.J., 1987, "Cointegration and Error Correction: Representation, Estimation and Testing," Econometrica, Vo1. 55 : 251-276.

Golettie, F. and Babu, S., 1994, "Market Liberalization and Market Integration of Maize Markets in Malawi," Agricultural Economics, Vo1. $11: 311-324$.

Golettie, F., A. Raisuddin, and N. Farid, 1995, "Structural Determinants of Market Integration: The Case of Rice Market in Bangladesh," Developing Economics, Vo1. 33 (2) : 185-202. 
Govt. of Pakistan, 2005-06, “Agricultural Statistics of Pakistan,” Ministry of Food, Agriculture and Livestock, Islamabad, Pakistan.

Granger, C. W.J., 1981, "Some Properties of Time Series Data and their Use in Econometric Mode1 Specification,” Journal of Econometrics, Vol. $16: 121-130$.

Granger, C.W.J., 1969, "Investigating Causal Relationships by Econometric Models and Cross Spectral Methods," Econometrica, Vo1. 37 : 424438 .

Granger, C.W.J., 1988, "Some Recent Developments in the Concept of Causality,” Journal of Econometrics, Vo1. 39 : 199-211.

Greene, W. H., 2000, Econometric Analysis, New Jersey: Prentice-Hall, Inc.

Harris, R., 1995, Using Cointegration Analysis in Econometric Modelling, London: Prentice Hall-Harvester Wheatsheaf.

Hayes, H.M. and J.H. McCoy, 1977, "Food Grain Marketing in Northern Nigeria: Spatial and Temporal Performance," Journal of Development Studies, Vo1. 14 (2) : 182-192.

Johansen S., 1991, "Estimation and Hypothesis Testing of Cointegration Vectors in Gaussian Vector Autoregressive Models," Econometrica, Vol. 59 : 551-1580.

Johansen S., 1995, Likelihood-Based Inference in Cointegrated VectorAutoregressions, In Advanced Texts in Econometrics, Oxford: Oxford University Press.

Johansen, S., 1988, "Statistical Analysis of Cointegration Vectors," Journal of Economic Dynamics and Control, Vo1. 12 : 31-254.

Johansen, S., 1992, "Determination of Cointegration Rank in the Presence of a Linear Trend," Oxford Bulletin of Economics and Statistics, Vo1. 54, 383-97.

Khan, A. M. S., 1980, Marketing Infrastructure, Margins and Seasonal Price Variation of Selected Agricultural Commodities in Sindh Province of Pakistan. Tandojam: Department of Agricultural Economics and Rural Sociology, Sindh Agriculture University. 
Khushk, A. M. and L.E.D. Smith, 1996, "A Preliminary Analysis of the Marketing of Mango in Sindh Province, Pakistan," The Pakistan Development Review, Vol. 35 (3) : 241-255.

Khushk, A. M., 1997, The Mango Production and Marketing System in Sindh Pakistan: Constraints and Opportunities. Ph.D. Thesis, Wye College, University of London, UK, October 1997.

Khushk, A.M., M. I. Lashari and M. Aslam, 2003, Constraints and Opportunities in Mango Production and Marketing in Sindh. Socioeconomic Research Studies 2002-03, Technology Transfer Institute, Tandojam, Sindh : 1-54.

Koh1, S. R. L and J. N. Uh1, 1998, Marketing of Agricultural Products, Fifth Edition, Macmillan, New York.

Lale, U., 1971, Food Grain Marketing in India: Private Performance and Public Policy, Ithaca, New York: Cornell University Press.

Lashari, M. I., A. M. Manganhar, S.K. Ali and M. U. Shar, 1995, Marketing of Mango in Sindh (edited by Ch. M. Manzoor Ali). Agricultural Economics Research Unit of Pakistan Agricultural Research Council, ARI, Tandojam, Sindh.

Lohano, D. H. and F. H. Mari, 2006, "Testing Market Integration in Regional Onion Markets of Pakistan: Application of Error Correction Model in the Presence of Stationarity," International Research Journal of Finance and Economics, Vo1. 1 : 89-97.

Memon, R.A., 1978, Marketing Infrastructure, Margins and Seasonal Price Variation of Selected Agricultural Commodities in Sindh Province of Pakistan. Department of Agricultural Economics and Rural Sociology, Sindh Agricultural University, Tandojam, Pakistan.

Mohy-ud-din, Q., 1989, Marketing of Major Fruits (Citrus and Mango) in Punjab. Department of Agricultural Marketing, Faculty of Agricultural Economics and Rural Sociology, University of Agriculture, Faisalabad.

Mukhtar, T. and M. Tariq, 2008, Market Integration in Wholesale Maize Markets in Pakistan. Paper presented in the 23rd Annual General Meeting and Conference of Pakistan Institute of Development Economists, Pakistan. 
Mushtaq, K., F. Abbas and Abeddulah, 2007a, "Testing the Law of One Price: Cotton Market Integration in Pakistan's Punjab, Pakistan,” Journal of Agricultural Sciences, Vo1. 44 (2) : 364-369.

Mushtaq, K., F. Abbas and Abeddulah, 2007b, "Government Interventions and Market Integration in Prominent Wheat Markets of Pakistan," Pakistan Journal of Agricultural Sciences, Vo1. 44 (2) : 356-360.

Mushtaq, K., F. Abbas., Abeddulah and A. Ghafoor, 2006, "Testing the Law of One Price: Rice Market Integration in Punjab, Pakistan,” Pakistan Journal of Agricultural Sciences, Vo1. 43 (3-4) : 213-216.

Negassa, A., R. Meyers and E. G. Maldhin, 2003, "Analyzing the Grain Market Efficiency in Developing Countries: Review of Existing Methods And Extensions to the Parity Bound Mode1, Market Trade and Institutions Division, Discussion Paper : 63.

Potter, S. M., 1998, A Non-Linear Impulse Response Functions, Domestic Research Function, Federal Reserve Bank of New York, NY 10045 U.S.A.

Scarborough, V. and J. Kydd, 1992, Economic Analysis of Agricultural Markets: A Manual, Chatham Natural Resource Institute.

Sharif, M., 2004, Opportunities and Constraint in the Production and Marketing of Citrus in Punjab, PhD Thesis, Dept. of Farm Management, University of Agriculture, Faisalabad.

Siddiqui, S. A., 1977, Marketing Infrastructure, Margins and Seasonal Price Variation of Selected Agricultural Commodities in Sindh Province of Pakistan, Department of Agricultural Economics and Rural Sociology, Sindh Agricultural University, Tandojam, Pakistan.

Siddiqui, S.A., 1979, Marketing of Agricultural Products in Sindh. Department of Agricultural Economics and Rural Sociology, Sindh Agricultural University, Tandojam, Pakistan.

Sims, C. A., 1980, “Macroeconomics and Reality," Econometrica, Vo1. 48 : $1-49$.

Tahir, Z. and K. Riaz, 1997, "Integration of Agricultural Commodity Market in Punjab," The Pakistan Development Review, Vo1. 36 (3) : 241-262. 
Thakur, D. S., 1973, "Pricing Efficiency of Indian Apple Market," Indian Journal of Agricultural Economics, 28(4), 105-114.

Timmer, P.C., 1987, "Corn Marketing and the Balance between Domestic Production and Consumption," Working Paper No. 4, BURLOGStanford Corn Project.

Wyeth, J., 1992, "The Measurement of Market Integration and Application to Food Security Policies," Discussion Paper 314, Brighton: Institute of Development Studies, University of Success. 
Appendix: Graphical Analysis of Prices in Different Markets and Relation with Consumer Price Index

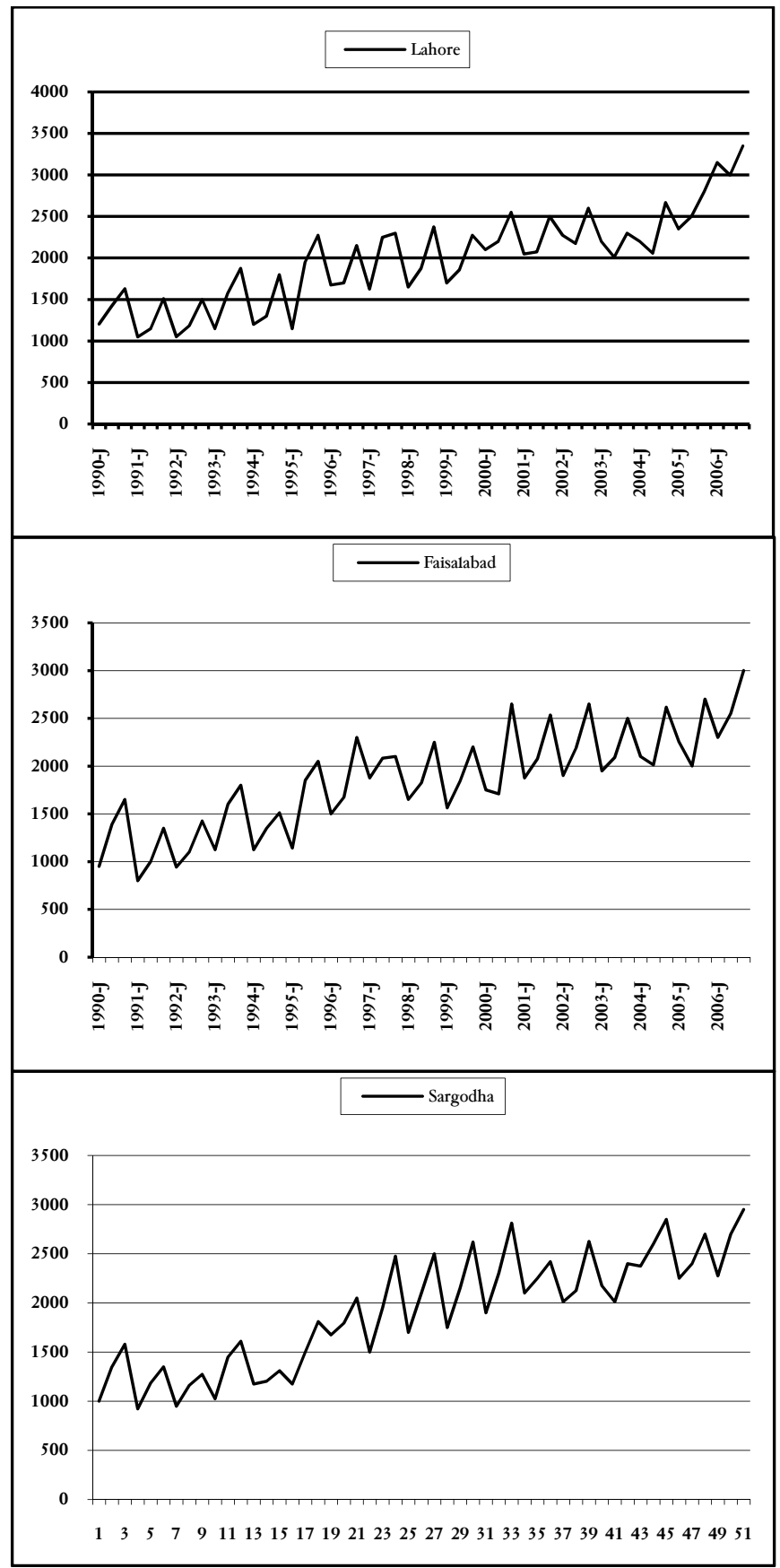




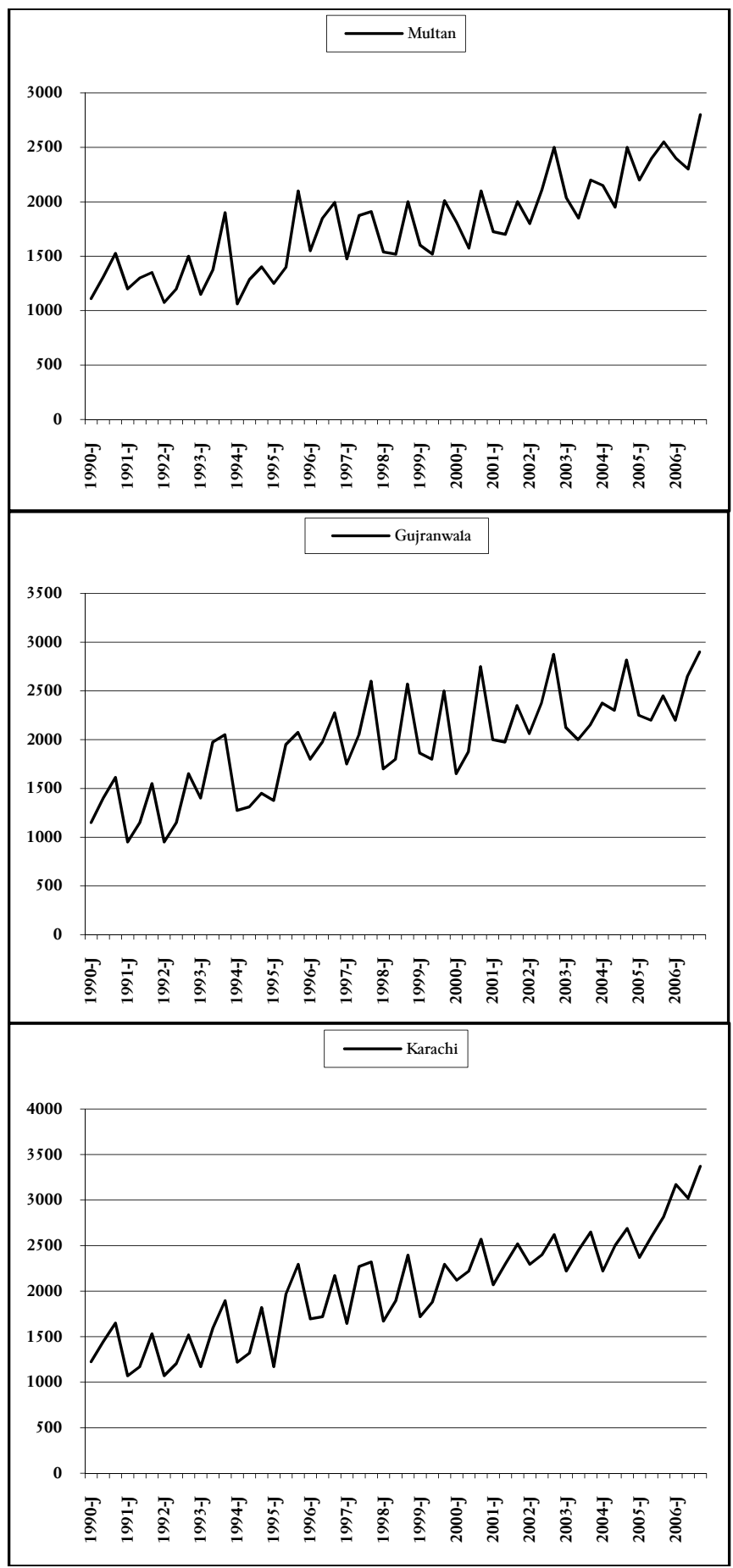




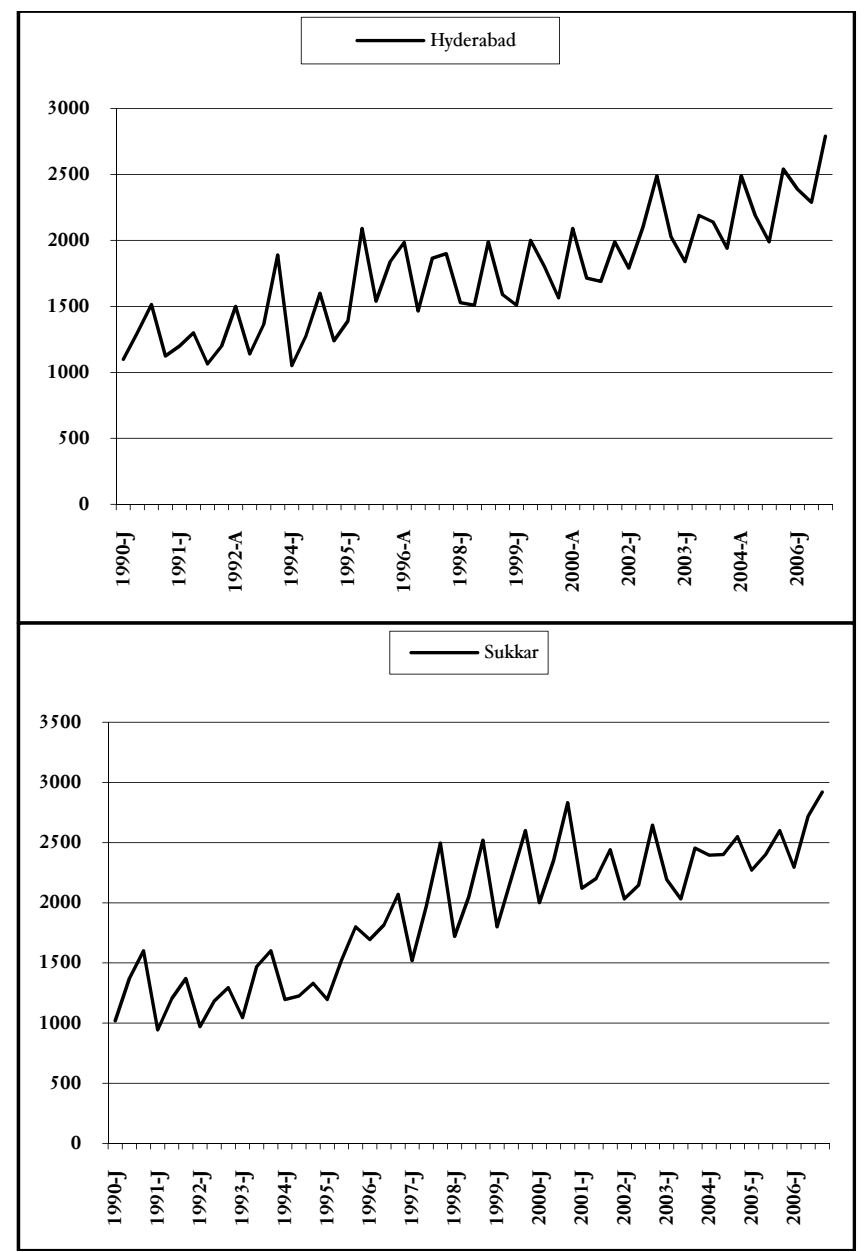



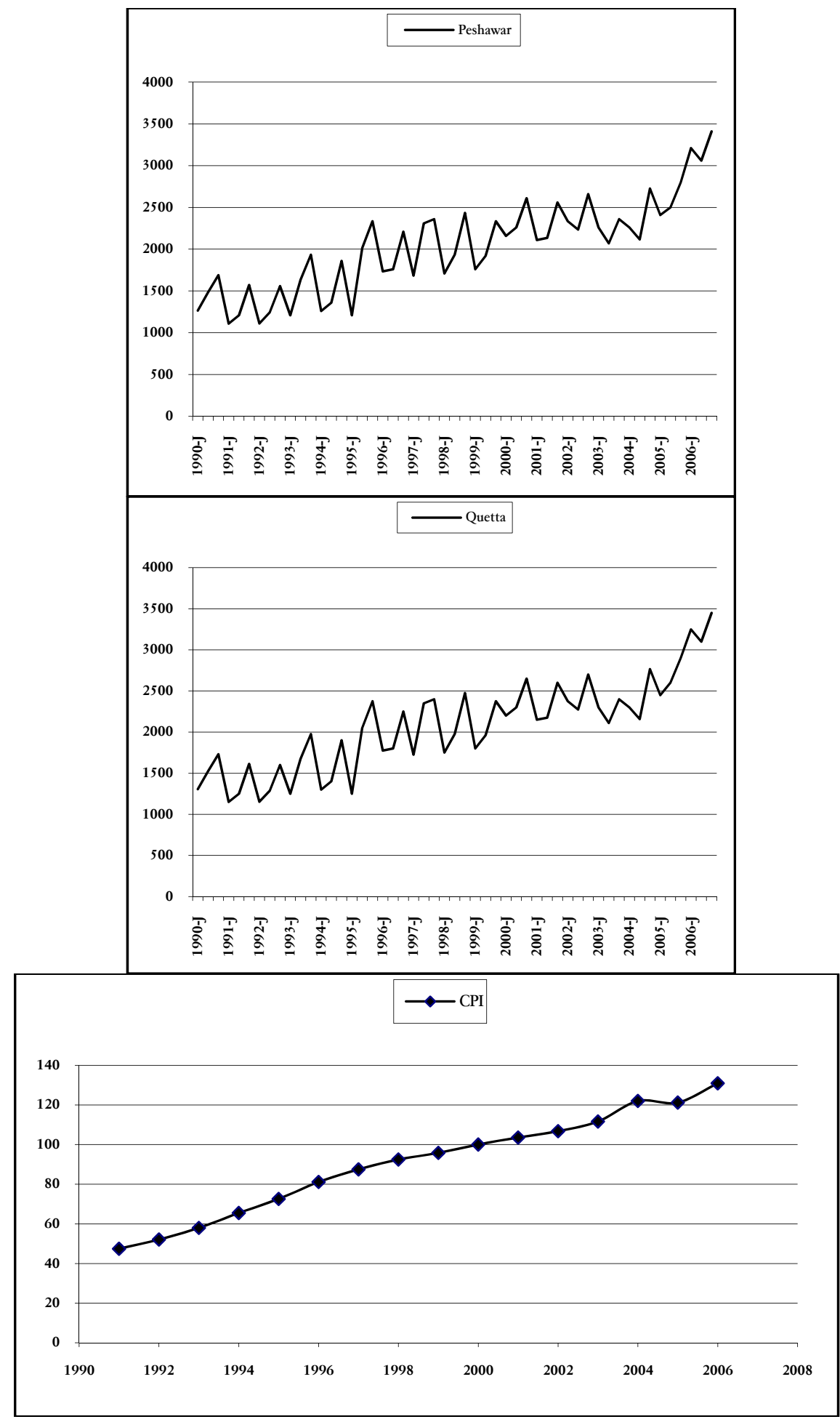